Original Research Article

\title{
Anti-anxiety activity of ethanolic extract of Spermacoce hispida leaves in swiss albino mice
}

\author{
Vinayak Meti ${ }^{1 *}, K_{\text {umaraswamy Dabburu }}^{2}$
}

${ }^{1}$ Department of Pharmacology, Chettinad Hospital and Research Institute, Kelambakkam, Kancheepuram 603103, Tamil Nadu, India

${ }^{2}$ Department of Pharmacology, SRM Medical College Hospital and Research Centre, Potheri, SRM Nagar, Kattankulathur, Kancheepuram 603203, Tamil Nadu, India

Received: 30 June 2017

Accepted: 24 July 2017

\section{*Correspondence to:}

Dr. Vinayak Meti,

Email: metivinayak@gmail.com

Copyright: (C) the author(s), publisher and licensee Medip Academy. This is an openaccess article distributed under the terms of the Creative Commons Attribution NonCommercial License, which permits unrestricted noncommercial use, distribution, and reproduction in any medium, provided the original work is properly cited.

\begin{abstract}
Background: The objective of the study was to evaluate the anxiolytic activity of ethanolic extract of Spermacoce hispida (EESH) in swiss albino mice.

Methods: Forty eight adult Swiss albino mice weighing 25-30grams were selected. 24 were allocated to Elevated plus maize test and the remaining 24 to Bright and dark box test models. In each model, there were 4 groups. The control group received normal saline $(10 \mathrm{ml} / \mathrm{kg})$, the standard, Diazepam $(1 \mathrm{mg} / \mathrm{kg})$ and test groups received ethanolic extract of Spermacoce hispida $(100 \mathrm{mg} / \mathrm{kg}$, $200 \mathrm{mg} / \mathrm{kg}$ p.o. respectively) $1 \mathrm{~h}$ prior to the acute study. In chronic study the drugs were given orally once a day for 10 days and the last dose was given $1 \mathrm{~h}$ before the experiment. The antianxiety activity of the test drug was evaluated using EPM test and Bright and dark box test experimental models of anxiety. All results were expressed as mean \pm standard error mean (SEM) and analysed by one-way ANOVA. Post-hoc comparisons were performed by applying Dunnet's test. P $<0.05$ was considered statistically significant.

Results: Ethanolic extract of Spermacoce hispida significantly increased the duration of time spent and number of entries in open arm in EPM and increased the number of entries into the bright arena, the time spent and the rears in bright arena indicating anxiolytic activity and EESH $200 \mathrm{mg} / \mathrm{kg}$ was found to be better than diazepam.
\end{abstract}

Conclusions: The results of the present study suggest that the ethanolic extract of Spermacoce hispida have anxiolytic activity better than Diazepam.

Keywords: Anxiety, Elevated plus maize, Bright and dark arena, Spermacoce hispida

\section{INTRODUCTION}

Anxiety is a normal emotional response which when chronic or severe becomes pathological and can aggravate cardiovascular and psychiatric disorders. ${ }^{1}$ Despite the development of new molecules for pharmacotherapy of anxiety, the treatment is challenging as they produce various side effects or exhibit tolerance on continuous use.

Ayurvedic medicine is essentially promotive and preventive in therapeutic approach. Many Ayurvedic medicines are used for treating various neurological diseases. Spermacoce hispida, is one of them and it belongs to the family Rubiaceae and is popularly known as "Nattaiccuri" in Tamil or "Shaggy button weed" in English. It is widely distributed in the Western Ghats of Kerala and in Maruthamalai forest, which is an extension of Western Ghats in Tamil Nadu. ${ }^{2}$ The seed extract of the plant, has been used as a remedy for the treatment of internal injuries of nerves and kidney. It is suggested that it removes signs of old age, purify blood and improve vitality, and has been used by the tribal's living in the 
forest regions in the Western Ghats of Kerala since ancient times. It has also been reported that Spermacoce hispida, is an effective natural drug which has antidiabetic, Hepatoprotective, anti-inflammatory and antioxidant properties. $^{3-6}$ As for anti-anxiety activity, no conclusive data is available. Hence it was decided to evaluate the antianxiety effect of Spermacoce hispida on the animal models of anxiety.

Aim of the study was to evaluate the antianxiety activity of ethanolic extract of Spermacoce hispida (EESH) in Swiss albino mice on EPM and bright and light arena models.

\section{METHODS}

\section{Preparation of ethanolic extract of Spermacoce hispida}

The plant materials were collected from Chennai, Tamil Nadu. The leaves of the plant were dried under shade for one month. After complete drying, leaves were pulverized to a coarse powder in a mechanical grinder. $1000 \mathrm{~g}$ of powder was extracted using $95 \% \mathrm{v} / \mathrm{v}$ ethanol as a solvent in Soxhlet apparatus $\left(60-70^{\circ} \mathrm{C}\right)$ for about 15 cycles. The extracts were concentrated by distillation and filter it rapidly through Whatman No. 1 filter paper. Moisture was evaporated to dryness under reduced pressure and controlled temperature by using roto-evaporator. The yield was $11.29 \% \mathrm{w} / \mathrm{w}$ and it was transferred to clean sample bottle and stored at $4^{\circ} \mathrm{C}$ in a refrigerator until further use.

\section{Animals}

Adult male Swiss albino mice weighing 25-35g obtained from our animal house. The animals were housed at $24 \pm 2{ }^{\circ} \mathrm{C}$ with $12: 12 \mathrm{~h}$ light and dark cycle. They had free access to food and water. The animals were acclimatized for a period of 7 days before the study. The experimental protocol was approved by the Institutional Animal Ethics Committee (IAEC) of Chettinad Hospital and Research Institute, Chettinad University, Chennai, India. The animals were used according to the CPCSEA guidelines for the use and care of experimental animals.

\section{Experimental design}

On the day of the experiment, the animals were divided randomly into control and experimental groups $(n=6)$. Group 1 received the vehicle, normal saline $(10 \mathrm{ml} / \mathrm{kg})$ and served as the control group, group 2 received the standard drug diazepam $(1 \mathrm{mg} / \mathrm{kg})$ and group 3 and 4 received ethanolic extract of Spermacoce hispida $(100 \mathrm{mg} / \mathrm{kg}$, $200 \mathrm{mg} / \mathrm{kg}$ p.o. respectively). Drugs were administered to the animals 60 minutes prior to the evaluation in acute study, for chronic study once daily for a period of 10 days. Behavioural evaluation was carried out 60 minutes post drug administration on the $10^{\text {th }}$ day. The antianxiety activity of the test drug was evaluated using EPM test and Bright and dark box test experimental models of anxiety.
Table 1: Experimental design.

\begin{tabular}{|lll|}
\hline Groups & Treatment & Dose \\
\hline I & Normal saline & $10 \mathrm{ml} / \mathrm{kg}$ \\
\hline II & Diazepam & $1 \mathrm{mg} / \mathrm{kg}$ \\
\hline III & EESH & $100 \mathrm{mg} / \mathrm{kg}$ \\
\hline IV & EESH & $200 \mathrm{mg} / \mathrm{kg}$ \\
\hline
\end{tabular}

\section{Evaluation of antianxiety activity}

\section{Elevated Plus Maze Test}

According to the method of Kulkarni SK, et al. ${ }^{7}$ The wooden maze consisted of two open arms $(50 \mathrm{~cm} \times 10 \mathrm{~cm})$ and two closed arms of $(50 \mathrm{~cm} \times 10 \mathrm{~cm} \times 40 \mathrm{~cm})$. The arms of same type were opposite to each other with a central square of $10 \mathrm{~cm}$. The maze was elevated to a height of $50 \mathrm{~cm}$ above the floor. Each animal was placed in the centre square of plus maze, facing one of the open arms. The number of entries into and the time spent in open and closed arms in a 5 min period was noted.

\section{Bright and dark}

The apparatus consisted of an open top wooden box. Two distinct chambers, a black chamber $(20 \times 30 \times 35 \mathrm{~cm})$ painted black and illuminated with dimmed red light and a bright chamber $(30 \times 30 \times 35 \mathrm{~cm})$ painted white and brightly illuminated with $100 \mathrm{~W}$ white light sources, were located $17 \mathrm{~cm}$ above the box. The two chambers were connected through a small open doorway $(7.5 \times 5 \mathrm{~cm})$ situated on the floor level at the centre of the partition. ${ }^{8}$

\section{Behavioral assessment}

Each animal was tested initially in plus maze and, then, in bright and dark arena paradigm in a single setting. In acute study $60 \mathrm{~min}$ after and in chronic study $60 \mathrm{~min}$ after the last dose on the $10^{\text {th }}$ day of drug or vehicle administration, each animal was placed in the centre square of the plus maze, facing one of the open arms. The number of entries into and the time spent in open and closed arms and the number of rears in each arm in a five-minute period was noted.

Following the elevated plus maze test, the animal was placed at the centre of the brightly lit arena in the light and dark box. The number of entries into and the time spent in the bright arena, the number of rears in the bright arenas were noted. Following each trial, the apparatus were cleaned to mask the odour left by the animal in the previous experiment. Hand operated counters and stop watches were used to score the behavior of animals.

\section{Statistical analysis}

All results were expressed as mean \pm standard error mean (SEM) and analysed by one-way ANOVA. Post-hoc 
comparisons were performed by applying Dunnet's test. P $<0.05$ was considered statistically significant.

\section{RESULTS}

\section{Elevated plus-maze}

Administration of EESH (100 and $200 \mathrm{mg} / \mathrm{kg}$ ) significantly increased open arm activity, increasing the duration of time spent and number of entries in open arm in EPM test compared to control in acute study but in chronic study the doses of EESH produced a greater increase in duration of time spent and number of entries in open arm in EPM test compared to both control and standard drug diazepam. EESH $200 \mathrm{mg} / \mathrm{kg}$ had produced better effect than EESH $100 \mathrm{mg} / \mathrm{kg}$ and Diazepam in chronic study (Table 2 and Table 3).

Table 2: Acute effect of ethanolic extract of Spermacoce hispida on behaviour of mice in elevated plus maze.

\begin{tabular}{|lllll|}
\hline Groups & $\begin{array}{l}\text { Number of open } \\
\text { arm entries }\end{array}$ & $\begin{array}{l}\text { Number of total } \\
\text { arm entries }\end{array}$ & $\begin{array}{l}\text { Time spent in open } \\
\text { arm }\end{array}$ & $\begin{array}{l}\text { Time spent in closed } \\
\text { arm }\end{array}$ \\
\hline Control & $3.16 \pm 0.47$ & $6.50 \pm 0.72$ & $27.00 \pm 0.97$ & $182.67 \pm 2.33$ \\
\hline Diazepam $1 \mathrm{mg} / \mathrm{kg}$ & $8.50 \pm 0.67^{*}$ & $11.50 \pm 1.48^{*}$ & $100.66 \pm 1.33^{*}$ & $139.50 \pm 3.31^{*}$ \\
\hline EESH $100 \mathrm{mg} / \mathrm{kg}$ & $6.33 \pm 0.66^{*}$ & $9.16 \pm 0.70^{*}$ & $86.83 \pm 0.79^{*}$ & $164.67 \pm 2.20^{*}$ \\
\hline EESH $200 \mathrm{mg} / \mathrm{kg}$ & $7.33 \pm 0.49^{*}$ & $10.66 \pm 1.69^{*}$ & $88.50 \pm 1.34^{*}$ & $152.50 \pm 2.17 *$ \\
\hline
\end{tabular}

Values represented mean $\pm \mathrm{SEM},(\mathrm{n}=6), * \mathrm{P}<0.05$ vs. control

Table 3: Chronic effect of ethanolic extract of Spermacoce hispida on behaviour of mice in elevated plus maze.

\begin{tabular}{|ll|lll|}
\hline Groups & $\begin{array}{l}\text { Number of open } \\
\text { arm entries }\end{array}$ & $\begin{array}{l}\text { Number of total } \\
\text { arm entries }\end{array}$ & $\begin{array}{l}\text { Time spent in open } \\
\text { arm }\end{array}$ & $\begin{array}{l}\text { Time spent in closed } \\
\text { arm }\end{array}$ \\
\hline Control & $4.39 \pm 0.94$ & $8.35 \pm 0.65$ & $29.48 \pm 1.52$ & $234.92 \pm 2.79$ \\
\hline Diazepam $1 \mathrm{mg} / \mathrm{kg}$ & $8.05 \pm 0.62 *$ & $11.97 \pm 1.36^{*}$ & $88.93 \pm 1.07 *$ & $197.08 \pm 2.32^{*}$ \\
\hline EESH $100 \mathrm{mg} / \mathrm{kg}$ & $9.60 \pm 1.06^{*}$ & $15.00 \pm 1.33^{*}$ & $102.87 \pm 0.80^{*}$ & $170.32 \pm 1.39 *$ \\
\hline EESH $200 \mathrm{mg} / \mathrm{kg}$ & $10.22 \pm 0.78^{* *}$ & $15.30 \pm 0.70 *$ & $104.09 \pm 1.24 * *$ & $158.02 \pm 2.12 * *$ \\
\hline
\end{tabular}

Values represented mean \pm SEM $(\mathrm{n}=6), * \mathrm{P}<0.05$ vs. control, $* * \mathrm{P}<0.05$ vs. standard

\section{Bright and dark}

Table 4: Acute effect of ethanolic extract of Spermacoce hispida on behaviour of mice in bright and dark arena.

\begin{tabular}{|llll|}
\hline Groups & $\begin{array}{l}\text { Number of } \\
\text { bright } \\
\text { chamber } \\
\text { entries }\end{array}$ & $\begin{array}{l}\text { Time spent } \\
\text { bright } \\
\text { chamber } \\
\text { (sec) }\end{array}$ & $\begin{array}{l}\text { Number } \\
\text { of rears in } \\
\text { bright } \\
\text { chamber }\end{array}$ \\
\hline Control & $1.6 \pm 0.61$ & $5.16 \pm 0.30$ & $1.09 \pm 0.31$ \\
\hline $\begin{array}{l}\text { Diazepam } \\
1 \mathrm{mg} / \mathrm{kg}\end{array}$ & $2.66 \pm 0.23^{*}$ & $14.83 \pm 0.71^{*}$ & $3.32 \pm 0.75^{*}$ \\
\hline $\begin{array}{l}\mathrm{EESH} \\
100 \mathrm{mg} / \mathrm{kg}\end{array}$ & $2.45 \pm 0.45^{*}$ & $26.16 \pm 0.64^{*}$ & $2.80 \pm 0.15^{*}$ \\
\hline $\begin{array}{l}\mathrm{EESH} \\
200 \mathrm{mg} / \mathrm{kg}\end{array}$ & $2.74 \pm 0.21^{*}$ & $39.33 \pm 0.86^{*}$ & $3.18 \pm 0.74^{*}$ \\
\hline Values represented mean $\pm \mathrm{SEM}(\mathrm{n}=6),{ }^{*} \mathrm{P}<0.05$ vs. control
\end{tabular}

Diazepam $(1 \mathrm{mg} / \mathrm{kg})$ treated mice significantly increased the number of entries into the bright arena, the time spent and the rears in bright arena. In acute study, EESH (100 and $200 \mathrm{mg} / \mathrm{kg}$ ) significantly increased the number of entries into, time spent and rears in bright arena compared to control. EESH (100 and $200 \mathrm{mg} / \mathrm{kg}$ ) had shown significantly increased number of entries into, time spent and rears in bright arena when compared to control and diazepam in chronic study (Table 4 and Table 5).

Table 5: Chronic effect of ethanolic extract of Spermacoce hispida on behaviour of mice in bright and dark arena.

\begin{tabular}{|llll|}
\hline Groups & $\begin{array}{l}\text { Number of } \\
\text { bright } \\
\text { chamber } \\
\text { entries }\end{array}$ & $\begin{array}{l}\text { Time spent } \\
\text { bright } \\
\text { chamber } \\
\text { (seconds) }\end{array}$ & $\begin{array}{l}\text { Number of } \\
\text { rears in } \\
\text { bright } \\
\text { chamber }\end{array}$ \\
\hline Control & $1.31 \pm 0.73$ & $5.44 \pm 1.02$ & $2.18 \pm 0.24$ \\
\hline $\begin{array}{l}\text { Diazepam } \\
1 \mathrm{mg} / \mathrm{kg}\end{array}$ & $3.12 \pm 0.42 *$ & $16.23 \pm 0.12^{*}$ & $4.62 \pm 0.49^{*}$ \\
\hline $\begin{array}{l}\mathrm{EESH} \\
100 \mathrm{mg} / \mathrm{kg}\end{array}$ & $3.76 \pm 0.23^{*}$ & $29.71 \pm 0.43^{*}$ & $4.94 \pm 0.28^{*}$ \\
\hline $\begin{array}{l}\text { EESH } \\
200 \mathrm{mg} / \mathrm{kg}\end{array}$ & $5.35 \pm 0.27 * *$ & $45.31 \pm 0.94 * *$ & $6.76 \pm 0.35^{* *}$ \\
\hline
\end{tabular}

Values represented mean \pm SEM $(\mathrm{n}=6), * \mathrm{P}<0.05$ vs. control, $* * \mathrm{P}<0.05$ vs. standard

\section{DISCUSSION}

The two experimental models of anxiety, elevated plus maze and bright and dark arena, are based on the assumption that unfamiliar, non-protective and brightly lit 
environmental stress provokes inhibition of normal behaviour. This normal behavioural inhibition is further augmented in the presence of fear or anxiety like state.

In the elevated plus maze, the open arms are more fear provoking than the closed arms. The ratio of entries, time spent and rearing behaviour in open arms to closed arms reflects the safety of closed arms with relative fearfulness of open arms. ${ }^{9}$ The reduction in entry, time spent, total arm entries are the indications of high level of fear or anxiety. Anxiolytic drugs increase the proportion of entries, time spent in open arms.

In the bright and dark box paradigm, the brightly lit environment is a noxious environment stressor that inhibits the exploratory behaviour of rodents. Reduction in the number of entries, time spent and rearing behaviour in the bright chamber were regarded as markers of anxiety. ${ }^{8}$ Rearing reflects an exploratory tendency of the animal that can be reduced due to a high level of fear. ${ }^{10}$

In the present study, The EESH significantly increased the duration of time spent and number of entries in open arm, time spent in closed arm in EPM test indicating anxiolytic activity in both acute and chronic studies. They also showed an increase in the time spent and the rears in bright arena in the bright and dark arena paradigm. Anxiolytic activity of EESH $200 \mathrm{mg} / \mathrm{kg}$ was found to be greater than diazepam in chronic study. All these suggest decreased fear, an increased exploratory behaviour and the behavioural dis-inhibitory effect of the standard anxiolytic drug diazepam.

Beta-sitosterol and ursolic acid are the important phytoconstituents present in Spermacoce hispida, among them ursolic acid was reported to produce anti-anxiety activity. ${ }^{11,12}$ This could be the reason for the significant anti-anxiety activity seen in the current study.

\section{CONCLUSION}

The results of the present study suggest that the ethanolic extract of Spermacoce hispida have anxiolytic activity better than Diazepam. The phytochemical ursolic acid may be responsible for anxiolytic activity. Further studies are required to elucidate the possible mechanism of anxiolytic activity and its usefulness in human beings.

Funding: No funding sources

Conflict of interest: None declared

Ethical approval: The study was approved by the Institutional Ethics Committee

\section{REFERENCES}

1. Martin EI, Ressler KJ, Binder E, Nemeroff CB. The Neurobiology of Anxiety Disorders: Brain Imaging,
Genetics, and Psychoneuroendocrinology. The Psychiatric clinics of North America. 2009;32(3):54975.

2. Chellaiah M, Muniappan A, Nagappan R, Savarimuthu, I. Medicinal plants used by traditional healers in Kancheepuram District of Tamil Nadu, India. Journal of Ethnobiology and Ethnomedicine. 1999;2:43.

3. Kaviarasan K, Pugalendi KV. Influence of flavonoidrich fraction from Spermacoce hispida seed on PPARalpha gene expression, antioxidant redox status, protein metabolism and marker enzymes in high-fatdiet fed STZ diabetic rats. J Basic Clin Physiol Pharmacol. 2009;20(2):141-58.

4. Karthikeyan M, Wawdhane SS, Kannan M, Rajasekar S. Hepatoprotective activity of ethanolic extract of spermacoce hispida. linn against carbon tetrachloride (cc14) induced hepatotoxicity on albino wistar rats. International Journal of Pharma Research and Development. 2011;2:11.

5. Parthasarathy G. Evaluation of anti-inflammatory activity of methanolic extract of Spermacoce hispida Linn. J Pharm Res. 2010;3:1516-7.

6. Kaviarasan K, Kalaiarasi P, Pugalendi V. Antioxidant efficacy of flavonoid rich fraction from Spermacoce hispida in hyperlipidemic rats. Journal of Applied Biomedicine. 2008;6:165-76.

7. Kulkarni SK, Reddy DS. Animal behavioral models for testing antianxiety activity. Meth Find Exp Clin Pharmacol. 1996;18:219-40.

8. Costall B, Domeney AM, Gerrard PA, Kelly ME, Naylor RJ. Zacopride: Anxiolytic profile in rodent and primate models of anxiety. J Pharm Pharmacol 1988;40:302-5.

9. Pellow G, Chopin P, File SE, Briley M. Validation of open-closed arm entries in elevated plus maze as a measure of anxiety in the rat. J Neurosci methods 1985;14:149-67.

10. Van der poel AM. A note on stretched attention, A behavioral element indicative of an approachavoidance conflict in rats. Animal Behav. 1979;27:446-50.

11. Ankad GM, Konakeri RT, Hegde HV, Roy S. Variation in pharmacognostic characters and polyphenolic contents among four species of medicinal plants from the genus spermacoce (rubiaceae). Indian journal of pharmaceutical sciences. 2015 Jul;77(4):446.

12. Colla AR, Rosa JM, Cunha MP, Rodrigues AL. Anxiolytic-like effects of ursolic acid in mice. Eur $\mathbf{J}$ Pharmacol. 2015 Jul;758:171-6.

Cite this article as: Meti V, Dabburu K. Antianxiety activity of ethanolic extract of Spermacoce hispida leaves in swiss albino mice. Int $\mathbf{J}$ Basic Clin Pharmacol 2017;6:2224-7. 